\title{
ЗВ’ЯЗОК РОЗВ’ЯЗАННЯ ПРОБЛЕМИ ВАЖКОВИХОВУВАНОСТІ ПІДЛІТКІВ ІЗ РОБОТОЮ МЕДИЧНОЇ СЕСТРИ
}

\author{
В. Ю. Морванюк \\ ДВНЗ «Тернопільський державний медичний університет \\ імені І. Я. Горбачевського МОз Украӥни» \\ Уманський медичний коледж
}

У статті висвітлено результати аналізу наукових поглядів видатних педагогів із проблеми важковиховуваних підлітків. Відображено зв'язок розв'язання проблеми важковиховуваності підлітків із роботою медичної сестри.

\section{CONNECTION BETWEEN PROBLEM SOLUTION OF TROUBLED YOUTH AND THE WORK OF A NURSE}

\author{
V. Yu. Morvaniuk \\ I. Horbachevsky Ternopil State Medical University \\ Uman Medical College
}

The article highlights the results of the analysis of the scientific views of outstanding teachers on the problem of troubled youth. The connection between problem solution of troubled youth and the work of a nurse is shown.

Вступ. Педагогічний вплив на важковиховуваних підлітків у напрямі здоров'язбереження не може бути ізольованим від аналізу досвіду роботи з дітьми підліткового віку та поєднання професійної діяльності фахівців різного профілю (педагогів, психологів, медичних і соціальних працівників). Лише за таких умов формується глибоке осмислення зв'язку історії з сьогоденням для вирішення однієї з актуальних проблем сучасності - формування морально і фізично здорового покоління.

Основна частина. Протягом останніх століть термін «важковиховуваність» пройшов низку перетворень. Ще в першій половині XIX століття важковиховуваними вважали лише дітей з різко вираженими фізичними вадами: сліпих, глухих, глухонімих тощо. Такий аспект характеристики важковиховуваності свідчить про медичні проблеми в здоров'ї підлітків. Так, відомий психолог Л. Виготський головною причиною важковиховуваності вважав труднощі підліткового періоду з його інтенсивним анатомофізіологічним і психологічним розвитком, підвищеною збудженістю, швидкою вразливістю, неузгодженістю психологічних процесів. Тому в цьому віці, на думку

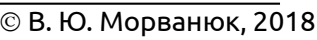

науковця, $є$ велика небезпека різних патологічних, травматичних впливів [2].

Найчастіше в літературі використовують терміни «важке дитинство»; «морально дефективний», «бездоглядний», що окреслює цю проблему як соціальну. Зокрема П. Блонський вважав, що не можна всі причини важковиховуваності підлітків відносити до спадковості та патології дитини, варто враховувати також умови, в яких виникає хвороба - соціальна спадковість. Підтримує цю думку Л. Виготський, висловлюючи власне розуміння: «Своєрідність важкої дитини складається в процесі розвитку, а не дана одвічно в її первинних дефектах» [2].

Особливий аспект проблеми важковиховуваності полягає в тому, що не лише з важковиховуваними підлітками важко, але й їм важко через невлаштованість життя, непідготовленість до нього. Так, А. Макаренко підкреслював, що людина погана лише через те, що перебуває в поганій соціальній структурі, в поганих умовах [4]. На думку польського педагога Я. Корчака, дитина недисциплінована і зла тому, що вона страждає. Таке розуміння поєднує педагогічні, психологічні та медичні аспекти в характеристиці важковиховуваності підлітків. 
До певної міри важковиховуваними можна вважати педагогічно занедбаних дітей. Педагогічно занедбані діти - це майже здорові діти (фізично та психічно), які стали «важкими» через відсутність або неправильне виховання. Ці діти задовольняють власні бажання, не враховуючи вимог дорослих, які знаходяться поруч. Тобто відхилення від норм поведінки набувають у них стійкості. Так, В. Баженов вважає, що не варто ототожнювати поняття «педагогічна занедбаність» і важковиховуваність, оскільки, на його думку, «важковиховуваність учнів передує їх педагогічній занедбаності» [1]. Під важковиховуваними дітьми варто розуміти ті категорії дітей, у яких розвиваються якісні зміни в поведінці при довготривалому впливі несприятливого соціального середовища, що позначається на їхньому психофізичному зростанні (що можна розглядати і як медичну проблему). У деяких випадках важкого дитинства біологічна завантаженість сама по собі, будучи соціально зумовленою, може відігравати певне значення.

У загальноприйнятому розумінні до важковиховуваних належать фізично здорові діти, у поведінці яких спостерігають неорганізованість, недисциплінованість, хуліганство, правопорушення, опір виховним впливам.

Видатні педагоги С. Шацький, В. Сорока-Росинський, А. Макаренко, В. Сухомлинський та інші внесли значний доробок у справу вивчення важковиховуваної особистості. Вони не припускали думки, що виховання безсиле виправити деякі відхилення від норми моральної поведінки окремих підлітків; виступали проти ідеї дефективності дітей. Так, С. Шацький уточнює розуміння змісту дитячого життя, а саме підліткового віку, що складається з фізичного розвитку дитини (що значною мірою залежить і від рівня медичного догляду), матеріальної і розумової праці, гри, мистецтва, соціальної діяльності. Важковиховувані звикають до свого неблагополучного становища в сім'ї, шкільному колективі, перестають вірити у власні сили. Щоб виправити ці недоліки, слід перебудувати ставлення дітей до себе, до оточуючих людей, створити такі психолого-педагогічні ситуації, які дозволили б їм виявити позитивні якості особистості. Крім того, такі методи педагогічного впливу на них, як навіювання, розрив небажаних стосунків, контактів, переорієнтація міжособистісних відносин, трансформація негативних стосунків у позитивні, дають бажані наслідки, якщо вони застосовуються разом з іншими методичними системами (медичними, соціальними).

На основі багаторічного педагогічного досвіду В. Сухомлинський встановив, що чимало дітей при- ходять до школи з травмованою психікою, і це вкрай негативно позначається на їхній поведінці. Незадовільний стан здоров'я, травмовану психіку, важковиховуваність дітей В. Сухомлинський пов'язував із недоліками сімейного виховання. Вивчаючи понад дві тисячі сімей, де діти мали негативний вплив батьків, він дійшов висновку, що «важка» дитина - це результат вад батьків, сімейного життя. В. Сухомлинський вважав, що багато батьків беруть шлюб непідготовленими до народження і виховання дітей, тому так легко віддають їху школи-інтернати, спеціальні школи. Діти відчувають, що вони не потрібні батькам і переживають це як страшну трагедію. Навчати і виховувати таких дітей в школі дуже важко. Видатний педагог стверджував, що суспільство повинно суворо перевіряти моральну готовність людей до створення сім'і [5]. У цьому контексті важливу роль відіграє робота шкільної медичної сестри.

Важливо мати на увазі, що, за В. Сухомлинським, почуття ворожнечі до оточуючих переходить у таких дітей в жорстокість, намагання зробити щось на зло тим, хто лише хоче здаватися добрим, а насправді поганий. Ніколи не досягне успіху вчитель чи шкільна медична сестра, якщо будуть намагатися вплинути на учня загальними словами про добро і справедливість. Тут повинні бути конкретні дійові заходи, які повністю захопили 6 усі сфери інтелекту дитини (наприклад, формування у підлітків розуміння шкідливого впливу на організм різних негативних чинників (алкоголю, наркотичних речовин, ранніх статевих відносин та їх наслідків тощо), які можуть призвести до згубного впливу на здоров'я організму, який росте.

У зв'язку з цим, мистецтво виховання В. Сухомлинський розумів більш глибоко. Виховання, вважав він, має багатогранні явища життя - духовні, моральні цінності, моральні стосунки між людьми, які оточують дитину, їх духовну культуру. Виховання він поділяв на два джерела: перше - організована діяльність в сім'і, школі (зусиллями вчителів і медичних працівників); друге - взаємостосунки між людьми, судження і моральні якості людини, які фіксуються дітьми незалежно від нашого бажання. I з цього виникає проблема: діти, незважаючи на піклування про них із боку батьків та суспільства, часто зазнають негативного впливу. Як це можна подолати? В. Сухомлинський відповідає: необхідно виховувати у підлітків свідому протидію всьому поганому. Педагог використовує при цьому медичний термін - виховувати «імунітет до зла», щоб підліток не був беззахисним перед поганим впливом [5].

Сутність виховання, за В. Сухомлинським, повинна полягати в умінні спонукати підлітка до оцінки своїх 
вчинків, у яких відображається його ставлення до людей, дійсності, до себе, свого здоров'я, стимулювати внутрішню роботу його розуму, серця, в процесі якої народжується ідейна переконаність, прагнення бути корисним суспільству. В. Сухомлинський підкреслював, що дуже важливо прищепити важковиховуваному підлітку впевненість у власних силах, навчити їх виділити доступне в реальному здійсненні, а недоступне залишити у перспективі й готувати підлітка до реалізації цього в майбутньому. Спілкування з важковиховуваними підлітками, на думку видатного педагога, повинно ґрунтуватися на основі доброзичливості, чуйності, щирості, об'єктивності, поваги. «Я твердо переконаний, що багато шкільних конфліктів, які нерідко закінчуються великим лихом, відбуваються від невміння вчителя говорити з учнями» [6]. Тому особливу роль у психолого-педагогічному впливі на підлітків відводять шкільним медичним сестрам, які не мають відношення до успішності учнів (не виставляють негативних оцінок, не вказують на погану поведінку), але мають змогу розширити інформативне поле дитини у напрямі збереження здоров'я. Адже важковиховувані підлітки дуже чутливо сприймають лагідне слово, уважне ставлення до них, чутливі до несправедливості. Тому важливо в роботі з ними в будьяких випадках порушення дисципліни вміти їх спокійно та доброзичливо вислухати, розібратися, в чому вони праві, а в чому винні, зрозуміти мотиви вчинку, ретельно роз'яснити помилки і «робити це потрібно так, щоб людина з'являлася перед нами з відкритим серцем, не замикалася, не бачила у наших гірких словах упередження» [3]. Душевна чуйність, знання психіки і психології дитини, терпіння і наполегливість - усе це сприяє тому, що розумовий розвиток «важкої» дитини вирівнюється, вона перестає бути «важкою».

«Важкі діти є, від них нікуди не подінешся, - писав В. Сухомлинський. Важка дитина, - це маленька людина, в якої з різних причин $є$ ненормальності, якісь відхилення в розумовому розвитку. Звичайні методи і прийоми виховання, які дають добрі результати в роботі з основною масою дітей, до важких дітей застосовувати марно, треба шукати якісь інші, особливі методи і прийоми виховання» [7].

Як ніхто інший, багато корисного для вирішення проблеми важковиховуваності зробив А. Макаренко, який твердив, що якщо дитина стає хуліганом, то в цьому винна не вона, а педагогічні методи.

Психолого-педагогічна проблема визначення цілей і засобів виховного процесу не висвітлена належною мірою і нині. Звідси стають зрозумілими випадки окремих проявів педагогічного песимізму щодо можливостей перевиховання учнів із відхиленнями у поведінці. Дехто з педагогів переконаний, що важковиховуваність, як правило, детермінована негативною спадковістю і тому не слід марнувати час на таких дітей. А. Макаренко категорично виступав проти того, щоб виділяти правопорушників в окрему групу, «окремий сорт людей». Він вважав, що виправити поведінку вихованця можна тільки в тому разі, коли перебудувати його характер - одну з найважливіших складових психологічної системи особистості. Залежно від характеру А. Макаренко розділяв важковиховуваних підлітків на правопорушників, безпритульних і дітей із сімей. «Хто важче з цих трьох категорій: правопорушники, безпритульні чи діти з сім'ї, - сказати важко, - писав він, - але я гадаю, що найважчі діти з сім'ї. Принаймні за складністю характерів, за їх яскравістю і опірністю, ці діти здаються мені в моєму досвіді найважчими» [4]. Це підкреслює доцільність співпраці сім'ї, вчителів, шкільних психологів та медичних сестер у роботі з важковиховуваними підлітками. Адже, як свідчать сучасні психологічні дослідження (Л. Божович, Є. Савонько, Л. Славіна та ін.), важливе значення в роботі з важковиховуваними підлітками має вивчення їх особистості в цілому.

Нині на Заході існує багато різних течій, тенденцій, напрямів, теорій, концепцій щодо виховання і перевиховання важковиховуваних підлітків, які можна класифікувати за такими трьома напрямами: біосоціальний, соціологічний та критичний. Кожен із цих напрямів розглядає різні способи проведення профілактичних заходів щодо попередження важковиховуваності підлітків. У цьому випадку можна виділити такі три групи по роботі з даною категорією підлітків: правовий, медико-біологічний, соціальний.

Висновки. Прогресивні педагоги і психологи різних поколінь створили систему поглядів на таке складне соціально-біологічне явище, яким $є$ важковиховуваність. Вони розкрили реальні механізми процесу, який детермінує негативну поведінку дитини. Це все дає змогу модернізувати профілактику і подолання важковиховуваності в підлітків, визначати оптимальну структуру перевиховання. Крім того, з'являється можливість досить точно прогнозувати поведінку важковиховуваності окремої дитини і шляхів її попередження, використовуючи досвід роботи вчителів, психологів і медичних працівників. 


\section{СПИСОК ЛІТЕРАТУРИ}

1. Баженов В. Г. Воспитание педагогически запущенных подростков / В. Г. Баженов. - К. : Радянська школа, 1986. - 130 с.

2. Выготский Л. С. Трудное детство : Собрание сочинений : в 6 т. / Л. С. Выготский. - М. : Изд. МГУ, 1995. T. 3. -159 с.

3. Виноградова-Бондаренко В. Втілення ідей В. О. Сухомлинського в роботі з важковиховуваними дітьми / В. Виноградова-Бондаренко // Наукові записки ТдпУ ім. В. Гнатюка : Педагогіка. - Тернопіль, 2002. - № 5. C. 151-154.
4. Макаренко А. С. Деякі висновки $з$ педагогічного досвіду : твори : в 7 т. / А. С. Макаренко.- К., 1954. Т. 5. - С. 209-298.

5. Сухомлинський В. О. Батьківська педагогіка / В. О. Сухомлинський. - К. : Радянська школа, 1978. - 263 с.

6. Сухомлинский В. А. Трудные дети : избр. пед. соч. : в 3 т. / В. А. Сухомлинский. - М., 1981. - Т. 3. - С. 451-455.

7. Хромова О. В. О. Сухомлинський про виховання важких дітей і підлітків / О. Хромова // Наукові записки ТдПУ ім. В. Гнатюка : Педагогіка. - Тернопіль. - 2002. № 5. - С. 149-151.

Отримано 10.04.18 